\title{
HUMERAL NAIL: COMPARISON OF THE ANTEGRADE AND RETROGRADE APPLICATION
}

\author{
Ivan Benčić ${ }^{1}$, Tomislav Čengić ${ }^{1}$, Jakov Prenc ${ }^{1}$, Nikola Bulatović ${ }^{2}$ and Aljoša Matejčić ${ }^{1}$ \\ ${ }^{1}$ Clinical Department of Traumatology, Sestre milosrdnice University Hospital Center, Zagreb, Croatia; ${ }^{2}$ Clinical \\ Department of Orthopedic Surgery and Traumatology, University Center of Montenegro, Podgorica, Montenegro
}

\begin{abstract}
SUMMARY - Application of humeral nail in the treatment of humeral shaft fractures is a relatively novel method of fracture fixation. Its application at Clinical Department of Traumatology, Sestre milosrdnice University Hospital Center began in 2001. The operative procedure should be performed using a minimally invasive technique without fracture opening in order to maintain optimal conditions for fracture healing including hematoma management. However, in everyday practice it is often impossible to obtain satisfactory fracture reduction using the closed procedure, so open reduction and additional fixation with wires or screws are mandatory. Over the last 14 years, fixation of fractures with the locking nail was performed in more than 400 patients. Cases of pseudarthrosis and pathological fractures were also managed successfully. There were more female patients. The mean time from injury to surgery was 2.4 days. Surgery was performed immediately upon admission to the emergency service whenever possible. This study comprised 234 patients with humeral shaft fractures treated with the humeral nail (antegrade insertion was applied in 103 and retrograde in 131 patients). The aim of the study was to stress out the complexity of appropriate operative treatment of humeral shaft fractures using intramedullary fixation, as well as the importance of proper reduction and stable fixation.
\end{abstract}

Key words: Humerus fractures; Fracture fixation, intramedullary - methods; Bone nails - utilization

\section{Introduction}

Application of humeral nails in the treatment of humeral shaft fractures is a relatively novel method of fracture fixation. Its wide implementation began in the last decade of the $20^{\text {th }}$ century and was accepted in everyday practice after intramedullary nailing for the femur and tibia ${ }^{1-6}$. Its application at Clinical Department of Traumatology, Sestre milosrdnice University Hospital Center began in 2001. As compared to nails used in the femur and tibia, for insertion of humeral nail it is not the practice to drill the medullary canal

Correspondence to: Ivan Benčić, MD, Clinical Department of Traumatology, Sestre milosrdnice University Hospital Center, Zagreb, Croatia, Draškovićeva 19, HR-10000 Zagreb, Croatia E-mail: ivanbencictrauma@gmail.com

Received January 25, 2016, accepted February 27, 2016 and the size of the humeral nail has to be carefully chosen according to the size of the medullary canal. Humerus is not a weight bearing bone such as the femur or tibia and therefore is different in structure and elasticity. Humeral intramedullary drilling may cause iatrogenic fractures, especially in the elderly ${ }^{4}$. Humeral nail can be inserted into the humerus using either an antegrade (Figs. 1a and 1b) or retrograde approach (Figs. 2a and 2b).

\section{Antegrade nail insertion}

The rotator cuff injury during antegrade nail insertion may result in postoperative disorders during abduction and elevation of the upper $\operatorname{arm}^{2,6-9}$. With certain fracture types (usually a transverse mid-shaft humeral fracture) and suitable nail design, it is possible to avoid this type of complication, if the nail is inserted using the retrograde technique ${ }^{10-13}$. 


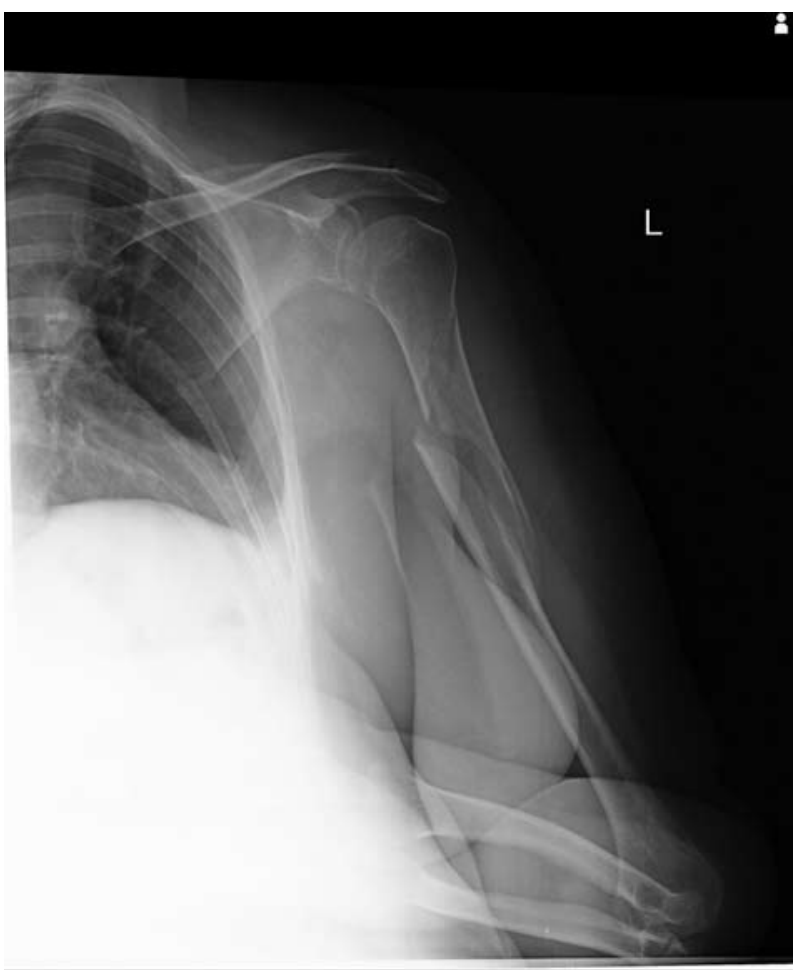

Fig 1.

a) Comminuted spiral fracture of the upper portion of the humeral shaft (plain AP x-ray).

During passage through the rotator cuff, it is highly recommended to make the smallest possible incision following the direction of tendon fibers and to repair the tendon after the nail has been inserted.

By antegrade nail insertion (Fig. 1b), lesions of other soft tissues are possible, such as axillary nerve, biceps tendon or circumflex arteries. Injuries of these structures are the consequence of proximal locking with guides, so that special care should be taken with mini incisions and insertion of guides to the bone. To avoid contact of the screw and the biceps tendon, it is wise to refrain from anteroposterior locking ${ }^{14-18}$.

Distal locking is performed using the so-called free hand technique under $\mathrm{x}$-ray control and is more complicated than distal locking in the femur or tibia. Imaging approach is more difficult; the surface of the supracondylar humerus is slick and narrow in the drilling zone. The approach is located in the anterolateral portion of the upper arm. If the drill bit is directed too far to the medial side, injury to the brachial artery or median nerve is possible (anteroposterior locking), and if it is located too close to the lateral side (latero-

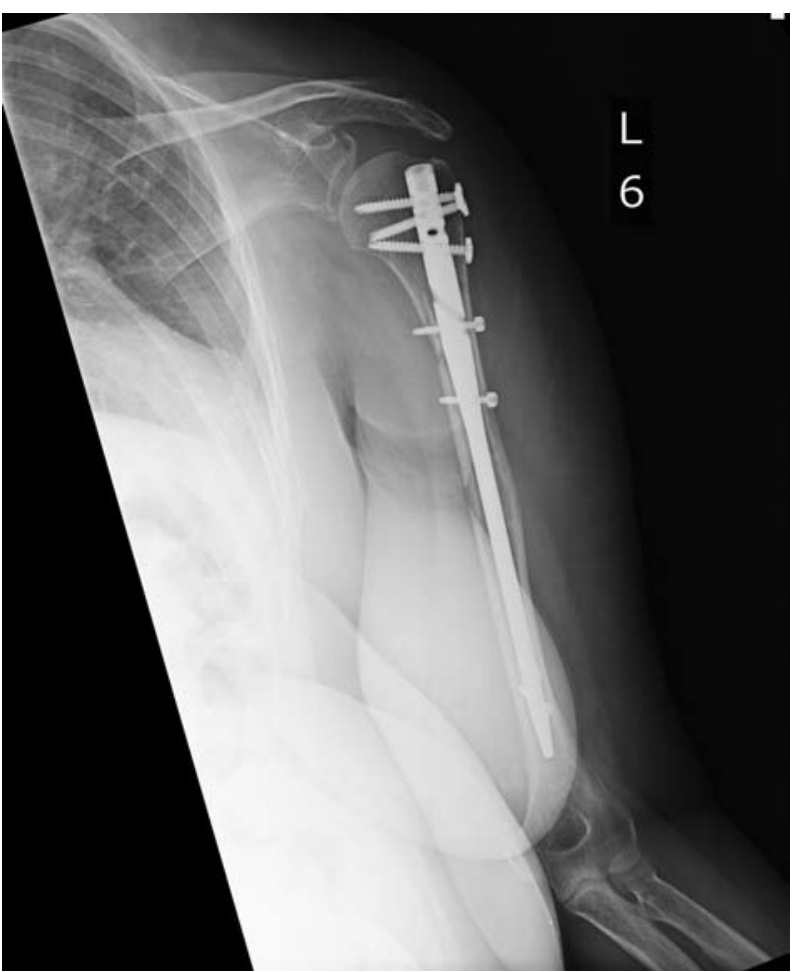

b) Reduction and antegrade nail fxation (plain AP x-ray).

medial locking), the radial or lateral cutaneous nerve can be damaged. When using these techniques, an open approach is recommended in order to avoid injuries of these structures. Depending on the type and level of fracture, one or two interlocking screws are placed. With the retrograde technique, the problem of damage to the neurovascular structures is not present because the locking is placed towards the posteroanterior side in the so-called safe zone ${ }^{19-24}$.

\section{Retrograde nail insertion}

Retrograde nail insertion (Fig. 2b) is technically more demanding that antegrade insertion because the position of the olecranon does not allow placement of the nail in the direction of the medullary canal axis. The nail enters the canal diagonally under a small angle, which may lead to a longitudinal fracture above the site of bone trepanation ${ }^{4,25}$. Therefore, trepanation must be done with great care. It starts 3-4 $\mathrm{mm}$ above the rim of the olecranon fossa and has an oval shape $(1 \times 2 \mathrm{~cm})$. Distal portion of the humerus below the fracture must be reamed manually $2 \mathrm{~mm}$ larger than the nail diameter ${ }^{4}$. 


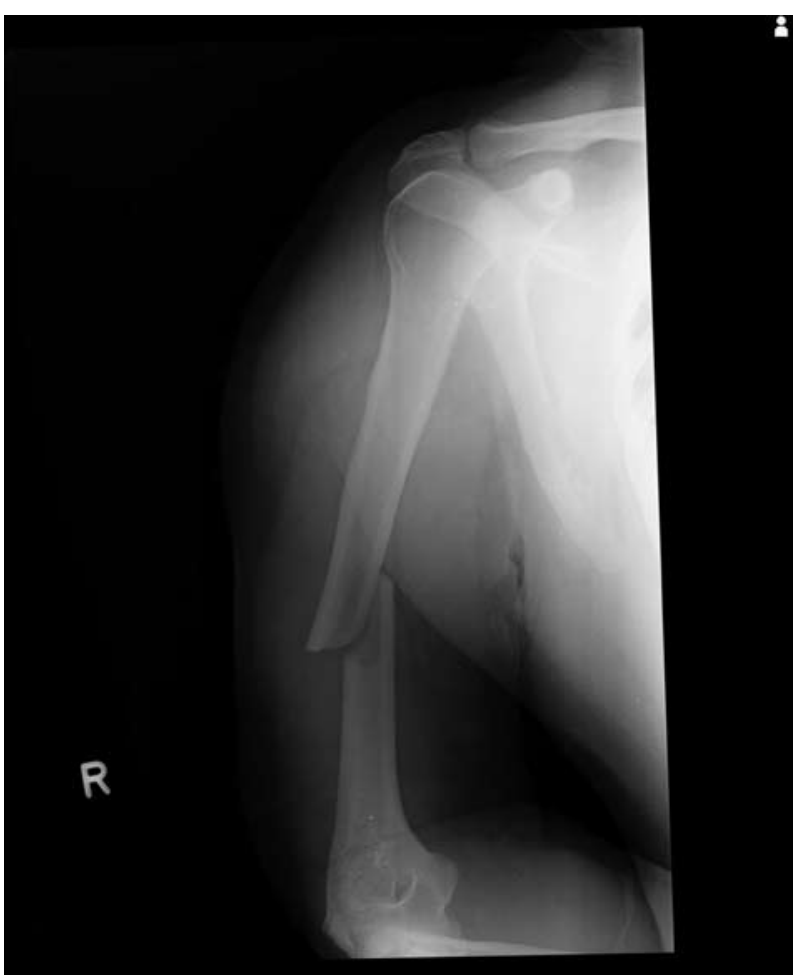

Fig 2.

a) Short oblique fracture of the humeral shaft (plain AP x-ray)

Distal locking is done using a guide in the anteroposterior (so-called safe zone).

Proximal locking is done using a free hand technique and the tip of the nail should be below the level of the surgical humeral neck ${ }^{13,26}$.

Complications associated with the proximal locking are injuries to soft tissues of the shoulder girdle, primarily to the axillary nerve ${ }^{24}$.

\section{Antegrade or retrograde technique}

Since antegrade insertion is associated with shoulder disorders, in case of mid-shaft fractures of the humerus, particularly in the middle third, the retrograde technique proves superior. However, if the fracture is located closer to the humeral head (Fig. 1a), it is more likely that the surgeon will choose the antegrade approach. In adipose patients or patients in poor general condition, prone position of the patient used for the retrograde technique may be associated with high anesthesia-related risks.

In young patients, a narrow medullary canal may be an obstacle for retrograde insertion. In such a case,

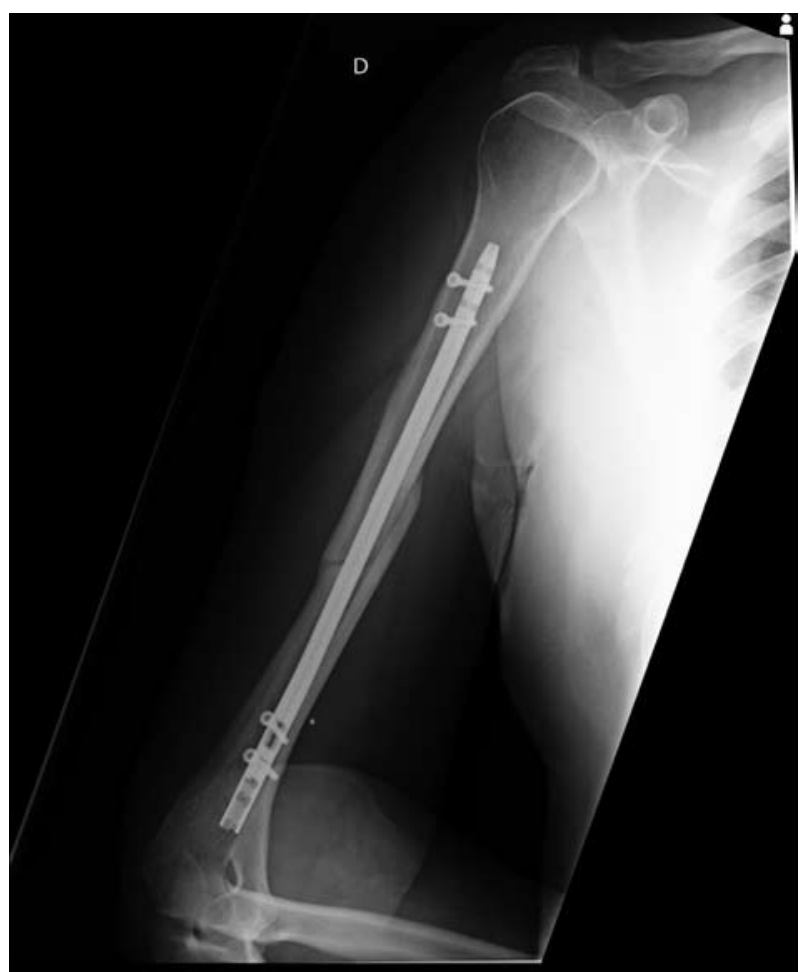

b) Reduction and retrograde nail fixation (plain AP x-ray)

it is easier to insert the nail into the narrow canal using the antegrade approach ${ }^{27}$.

\section{Medullary canal drilling?}

The humerus is not a weight bearing bone such as the femur or tibia, so drilling of the medullary canal is not necessary for the placement of a larger nail. The size of the medullary canal determines the size (width) of the nail. Moreover, segmental bone necrosis resulting from heat caused by drilling has been reported in the literature ${ }^{28}$. However, careful manual drilling is recommended with retrograde nail insertion. Medullary canal of the distal humerus is narrower than the proximal canal and the diameter of the distal portion of the canal must be $2 \mathrm{~mm}$ larger than the nail diameter in order to insert the nail into the canal without major problems.

\section{Materials and Methods}

Patients included in the study were operated during the 2003-2014 period. Fractures comprising prox- 
imal humerus (head and neck) were excluded. There were 126 female and 108 male patients.

\section{Time from injury to surgery}

In the majority of cases, surgery was performed on the same day or one day after the injury. Study patients were submitted to surgery one to six days after the injury (mean, 2.1 days after the injury). The reason for delay in operative treatment was comorbidity that required additional work-up studies or treatment, or the fact that some of the patients had been referred from other hospitals in Croatia.

\section{Types of humeral shaft fractures (assessed using the AO classification)}

- Comminuted spiral fractures of the upper portion of the humeral shaft ( $\mathrm{C} 1$ and $\mathrm{C} 3$ )

In this fracture type, three or four fragments are displaced by the attached muscles, mostly pectoral or deltoid muscle. As a rule, this fracture type was treated using the antegrade approach and nails with enhanced fixation in the humeral head. Screws were locked in the proximal portion of the nail and inserted in three or more planes and directions (Stryker PHN long and Diphos long nails). These fractures were often opened and loose fragments were reduced and fixed around the nail using a circulate wire.

- Long spiral fractures of the upper two-thirds of the humeral shaft

The approach most often applied was antegrade and no opening for reduction was necessary in the majority of cases.

- Short oblique and transverse fractures of the humeral shaft (A2, A3)

In this type, the retrograde approach was mostly used.

- Comminuted torsion fractures of distal diaphysis (B1, C1)

The retrograde approach was used in all cases. There were three or more fragments and the fracture was always exposed using the extended posterior approach directed proximally. The reduction was done during nailing procedure and fragments were fixed with circulate wire.

\section{Patient positioning}

In case of antegrade nail insertion, the patient was in the beach chair position on the operating table. The entire upper arm had to be available for x-ray monitoring, especially its distal portion due to the free hand screw locking.

In case of retrograde insertion, the patient was in prone position with abducted upper arm and flexed elbow. The upper arm was placed on the radiolucent operating table extension.

\section{Operative technique}

In the antegrade approach to the medullary canal, the site of trepanation was accessed through a small stab incision in front of the anterior rim of the acromion or through a small anterolateral approach to the humeral head. In both cases, the rotator cuff was incised longitudinally. The site of trepanation was in the lateral portion of the humeral head 2-3 mm medially to the great tubercle. The approach through the tubercle is not recommended due to the possible iatrogenic fracture. Trepanation to the medullary canal was done with a drill available in the instrument kit for fracture nailing. Reduction and nail insertion was done using a guide wire because cannulated nails were used in all cases. The medullary canal was not widened by drilling. During distal locking, the nail was rotated into its position in the canal, which allowed the anterolateral approach in the so-called safe zone to avoid radial nerve injury.

In the retrograde approach, the site of trepanation was accessed through a longitudinal posterior incision of the upper arm stretching from the olecranon to the proximal zone of the humeral shaft. The incision length depended on the type and level of the fracture; e.g., in case of a comminuted distal fracture of the shaft, it was possible to extend the incision proximally in order to achieve better control and visualization of the fracture. Trepanation site was positioned 2-3 mm above the olecranon fossa and its shape was oval and a bit wider than the nail. The nail was of a special design, a bit bended in the proximal and distal portion and of equal diameter along the entire length (UHN Stryker and Biotech). Only nails of such a design can be inserted retrograde without the danger of iatrogenic fracture in the trepanation zone. Distal portion of 
the medullary humerus is narrower than the proximal portion, so that the distal canal had to be widened by hand drilling: $2 \mathrm{~mm}$ wider than the chosen nail diameter. The nail was inserted up to the level of the surgical neck of the humerus, so that collision with the axillary nerve was avoided during proximal locking.

\section{Results}

Type 1 and type 2 fractures were more frequent in females, and type 3 and type 4 in male patients (Table 1). Consequently, the retrograde nail was used more often in males than in females (Table 2).

Difference in the incidence of the types of humeral fractures between males and females was statistically significant $\left(\chi^{2}\right.$-test $\left.=34.397, \mathrm{p}<0.01\right)$. Table 1 shows that type 1 and 2 fractures occurred more frequently in female, and type 3 and 4 in male patients.

Table 1. Patient distribution according to fracture type and sex

\begin{tabular}{|l|c|c|c|c|c|}
\hline Sex & Type 1 & Type 2 & Type 3 & Type 4 & Total \\
\hline Female & 66 & 32 & 18 & 22 & 138 \\
\hline Male & 21 & 10 & 31 & 34 & 96 \\
\hline Total & 87 & 42 & 49 & 56 & 234 \\
\hline
\end{tabular}

Table 2. Distribution of nail insertion site according to fracture type

\begin{tabular}{|l|c|c|c|c|}
\hline $\begin{array}{l}\text { Type of } \\
\text { fracture }\end{array}$ & $\begin{array}{c}\text { Type 1 } \\
(\mathrm{C} 1, \mathrm{C} 3)\end{array}$ & $\begin{array}{c}\text { Type 2 } \\
(\mathrm{A} 1, \mathrm{~B} 1)\end{array}$ & $\begin{array}{c}\text { Type 3 } \\
(\mathrm{A} 2, \mathrm{~A} 3)\end{array}$ & $\begin{array}{c}\text { Type 4 } \\
(\mathrm{B} 1, \mathrm{C} 1)\end{array}$ \\
\hline $\begin{array}{l}\text { Antegrade } \\
\text { insertion }\end{array}$ & 87 & 39 & 5 & 0 \\
\hline $\begin{array}{l}\text { Retrograde } \\
\text { insertion }\end{array}$ & 0 & 3 & 44 & 56 \\
\hline Total & 87 & 42 & 49 & 56 \\
\hline
\end{tabular}

\section{Discussion}

During many years of the humeral nail application for humeral fractures at Clinical Department of Traumatology, Sestre milosrdnice University Hospital Center, various operative procedures have come into use for different fracture types. The focus was set on proper reduction and stable fixation.

Transverse or short oblique fractures of the middle third of humeral diaphysis were treated using ret- rograde approach if the patient's condition allowed prone positioning and if there was an appropriate implant available. The contact between the nail and the bone was sufficient in the long portion of both the proximal and distal fragments. Good reduction and fixation were achieved and opening of the fracture site was not necessary except for patients with primary lesions of the radial nerve.

Spiral fractures of the middle third of the humeral shaft were treated through antegrade approach. Due to muscle shearing forces, the fracture was prone to dislocation even after nail insertion. Therefore, if the reduction was adequate after nail insertion, the fracture was left unopened. However, in case of persisting dislocation, a small anterolateral incision was done and the fracture was reduced using pliers and fixed with circulate wire. This was followed by proximal and distal locking with at least two screws at the nail end. In this way, an extremely firm fixation was obtained, which allowed early mobilization.

Comminuted fractures of the upper part of the humeral shaft were treated mostly by the antegrade approach. Following nail insertion, it was decided whether fracture should be opened and additional fixation with circulate wires applied based on the grade of fragment dislocation. Thus, higher fracture stability was achieved and in the follow up it was not noted that circulate wires affected fracture healing. On the contrary, poor stability often resulted in pseudarthrosis.

Comminuted fractures of the lower part of the humeral shaft were usually treated using the retrograde approach. The fracture was often located a few centimeters above the trepanation site, so that extended incision allowed good fracture exposure. During stabilization of these fractures, surgeons had to be very cautious with trepanation and nail insertion into the medullary canal in order to avoid the possible iatrogenic fractures. As a rule, a circulate wire had to be applied because additional dislocation of the fracture was possible during nail insertion.

The choice of the nail depended upon the fracture type, i.e. the fracture type dictated the type of the nail and approach. Whenever possible, the authors prefer retrograde insertion because the approach through the shoulder joint is avoided. Rotator cuff injury is a minor problem as compared to the onset of adhesions 
that make successful rehabilitation difficult. This problem also occurs with all other fixation methods applied through the shoulder. Retrograde nail insertion is more difficult but reduction is easier because the bone lies on a nail surface; free hand locking is also easier to perform because there is no danger of radial nerve injury. Locking is done below the surgical neck of the humerus in order to avoid damage to the axillary nerve. In our patient series, there were 5 intraoperative radial nerve injuries and no axillary nerve injury.

\section{Conclusion}

Adequate immobilization of humeral fractures is difficult, particularly in the elderly and obese. Nonoperative treatment is long and tedious for the patient, results in stiffness of neighboring joints and may lead to pseudarthrotic changes due to shearing muscle forces and instability.

By introducing intramedullary nails into everyday practice of humeral fracture treatment, indications for operative treatment of humeral fractures have been broadened. The nail allows minimally invasive approach in less complicated fractures; in case of complex fractures, it allows for bridging of the fracture site with or without circulate wires. Most importantly, it provides stable fixation, which prevents pains and increases significantly the possibility of good fracture healing. In addition to this, physical therapy can start earlier, which prevents joint stiffness.

The choice of approach to the medullary canal depends on the type and position of the fracture, patient's condition, and skill and affinities of the surgeon. During operative procedure, special attention should be paid to maintain proper reduction and stable fixation, as well as to preservation of neurovascular structures.

The learning curve is long but after the technique has been completely mastered by the surgeon, the reward is successful and quick healing of the fracture, early mobilization and patient's satisfaction.

\section{References}

1. Brumback RJ. The rationales of interlocking nailing of the femur, tibia, and humerus. Clin Orthop Relat Res. 1996;324:292-320. doi: 10.1007/s00132-008-1376-4.
2. Wallny T, Sagebiel C, Westerman K, Wagner UA, Reimer M. Comparative results of bracing and interlocking nailing in the treatment of humeral shaft fractures. Int Orthop. 1997;21:374-9. doi:10.1302/0301-620X.90B1. 19215.

3. WatanabeRS. Intramedullary fixation of complicated fractures of the humeral shaft. Clin Orthop Relat Res. 1993;292:25563.

4. Farragos AF, Schemitsch EH, McKee MD. Complications of intramedullary nailing for fractures of the humeral shaft: a review. J Orthop Trauma. 1999;13:258-67. doi:10.1302/0301620X.90B1. 19215.

5. Hems TE, Bhullar TP. Interlocking nailing of humeral shaft fractures: the Oxford experience 1991 to 1994. Injury. 1996;27:485-9.

6. Stern PJ, Mattingly DA, Pomeroy DL, Zenni EJ Jr, Kreig JK. Intramedullary fixation of humeral shaft fractures. J Bone Joint Surg Am. 1984;66:639-46. doi: 10.4103/00195413.33685 .

7. Brumback RJ, Bosse MJ, Poka A, Burgess AR. Intramedullary stabilization of humeral shaft fractures in patients with multiple trauma. J Bone Joint Surg Am. 1986;68:960-9.

8. Robinson CM, Bell KM, Court-Brown CM, McQueen MM. Locked nailing of humeral shaft fractures. Experience in Edinburgh over a two-year period. J Bone Joint Surg Br. 1992;74:558-62.

9. Riemer BL, D’Ambrosia R, Kellam JF, Butterfield SL, Burke CJ $3^{\text {rd }}$. The anterior acromial approach for antegrade intramedullary nailing of the humeral diaphysis. Orthopedics. 1993;16:1219-23.

10. Henley MB, Chapman JR, Claudi BF. Closed retrograde Hackethal nail stabilization of humeral shaft fractures. J Orthop Trauma. 1992;6:18-24.

11. Rommens PM, Verbruggen J, Broos PL. Retrograde locked nailing of humeral shaft fractures. A review of 39 patients. J Bone Joint Surg Br. 1995;77:84-9.

12. Blum J, Rommens PM, Janzing H. The unreamed humeral nail - a biological osteosynthesis of the upper arm. Acta Chir Belg. 1997;97:184-9.

13. Garnavos C, Lasanianos N, Kanakaris NK, Arnaoutoglou C, Papathanasopoulou V, Xenakis T. A new modular nail for the diaphyseal fractures of the humerus. Injury. 2009;40:60410. doi: 10.1016/j.injury.2009.01.130.

14. Bono CM, Grossman MG, Hochwald N, Tornetta P $3^{\text {rd }}$. Radial and axillary nerves. Anatomic considerations for humeral fixation. Clin Orthop Relat Res. 2000;373:259-64.

15. Albritton MJ, Barnes CJ, Basamania CJ, Karas SG. Relationship of the axillary nerve to the proximal screws of a flexible humeral nail system: an anatomic study. J Orthop Trauma. 2003;17:411-4.

16. Evans PD, Conboy VB, Evans EJ. The Seidel humeral locking nail: an anatomical study of the complications from locking screws. Injury. 1993;24:175-6. 
17. Prince EJ, Breien KM, Fehringer EV, Mormino MA. The relationship of proximal locking screws to the axillary nerve during antegrade humeral nail insertion of four commercially available implants. J Orthop Trauma. 2004;18:585-8.

18. Riemer BL, D'Ambrosia R. The risk of injury to the axillary nerve, artery, and vein from proximal locking screws of humeral interlocking nails. Orthopedics. 1992;15:697-9.

19. Garnavos C. Intramedullary nailing for humeral shaft fractures: the misunderstood poor relative. Curr Orthop. 2001;15:68-75.

20. Moran MC. Distal interlocking during intramedullary nailing of the humerus. Clin Orthop Relat Res.1995;317:215-8.

21. Kolonja A, Vecsei N, Mousani M, Marlovits S, Machold W, Vecsei V. Radial nerve injury after anterograde and retrograde locked intramedullary nailing of humerus. A clinical and anatomical study. Osteo Trauma Care. 2002;10:192-6.

22. Rupp RE, Chrissos MG, Ebraheim NA. The risk of neurovascular injury with distal locking screws of humeral intramedullary nails. Orthopedics. 1996;19:593-5. [PubMed]
23. Blyth MJG, Macleod CMB, Asante DK, Kinninmonth AWG. Iatrogenic nerve injury with the Russell-Taylor humeral nail. Injury. 2003;34:227-8.

24. Lin J, Shen PW, Hou SM. Complications of locked nailing in humeral shaft fractures. J Trauma.2003;54:943-9.

25. Lin J, Hou SM, Hang YS, Chao EYS. Treatment of humeral shaft fractures by retrograde locked nailing. Clin Orthop Relat Res. 1997;342:147-55.

26. Blum J, Engelmann R, Küchle R, Hansen M, Rommens PM. Intramedullary nailing of humeral head and humeral shaft Fractures. Eur J Trauma Emerg Surg. 2007;33:149-58.

27. Cheng HR, Lin J. Prospective randomized comparative study of antegrade and retrograde locked nailing for middle humeral shaft fracture. J Trauma. 2008;65:94-102.

28. Remiger AR, Miclau T, Lindsey RW, Blatter G. Segmental avascularity of the humeral diaphysis after reamed intramedullary nailing. J Orthop Trauma. 1997;11:308-11. doi: 10.1097/TA.0b013e31812eed7f.

Sažetak

\title{
USPOREDBA ANTEROGRADNE I RETROGRADNE APLIKACIJE HUMERALNOG ČAVLA
}

\author{
I. Benčič, T. Čengić, J. Prenc, N. Bulatović i A. Matejčić
}

Upotreba usidrenog humeralnog čavla u liječenju prijeloma i psudartroza nadlaktične kosti relativno je nova metoda fiksacije. U svijetu se počinje koristiti početkom 1990.-ih godina, a u Klinici za traumatologiju KBC-a Sestre milosrdnice primjenjuje se od 2001. godine. Operacija bi se u načelu trebala izvoditi minimalno invazivno bez otvaranja frakturnog predjela s ciljem očuvanja povoljnih lokalnih uvjeta za sanaciju prijeloma koje nam nudi frakturni hematom. Međutim, u praksi često nije moguće zadovoljavajuću repoziciju izvesti zatvoreno te je potrebno prijelom eksponirati i dodatno fiksirati serklažnim žicama ili vijcima. U posljednjih 13 godina fiksacija prijeloma s usidrenim čavlom učinjena je u preko 400 bolesnika. Uspješno su tretirane i pseudartroze i patološki prijelomi. Što se tiče spolne distribucije, prijelom je bio 2 puta više zastupljen u ženskoga spola. Srednje vrijeme od ozljede do operacije iznosilo je 2,4 dana. Ako su uvjeti i stanje bolesnika dozvoljavali, operacija se izvodila odmah nakon prijma u hitnoj službi. U ovoj studiji obrađeno je 234 bolesnika, od kojih je 110 bolesnika operirano retrogradnom aplikacijom, a 124 anterogradnom aplikacijom čavla. Cilj istraživanja bio je naglasiti složenost odgovarajućeg operativnog liječenja prijeloma dijafize humerusa koristeći intramedularnu fiksaciju, kao i važnost dobre repozicije i stabilne fiksacije ulomaka.

Ključne riječi: Humerus, frakture; Frakture, fiksacija, intramedularna-metode; Koštani čavli-primjena 